\title{
Adsorption Mechanism of Congo Red on Mg-Al-layered Double Hydroxide Nanocompound
}

\author{
Narges Safar Beyranvand, Babak Samiey* and Abbas Dadkhah Tehrani \\ Department of Chemistry, Faculty of Science, Lorestan University, Khoramabad 68137-17133, Lorestan, Iran \\ *Corresponding author: E-mail: babsamiey@yahoo.com, samiey.b@lu.ac.ir
}

Received: $12-25-2018$

\begin{abstract}
In this work, congo red (CR) was removed by applying carbonate intercalated Mg-Al-layered double hydroxide (MgAl-LDH) nanocompound as an adsorbent. Batch adsorption experiments performed under various temperatures, ionic strengths, initial CR concentrations, alkalinities and shaking rates. The maximum adsorption capacities of Mg-Al-LDH for CR were 100, 105 and $86.8 \mathrm{mg} \mathrm{g}^{-1}$ at 308, 318 and $328 \mathrm{~K}$, respectively. Adsorption sites of Mg-Al-LDH for CR were $-\mathrm{OH}$ groups attached to $\mathrm{Al}$ atoms of adsorbent layers. Adsorption isotherms of the process were studied by the ARIAN model and analysis of obtained data showed that there were two kinds of adsorption sites on the surface of Mg-Al-LDH. Results of instrumental analysis showed that these adsorption sites were - $\mathrm{OH}$ groups located on the surface of mesopores and micropores of adsorbent and were named MP and 003 sites, respectively. The kinetic data were studied by the KASRA model and ISO and intraparticle diffusion (pore-diffusion) equations which showed that CR molecules were adsorbed at first on the MP sites. Also, during the adsorption of CR on MP sites the interaction of CR with adsorbent surface was rate-controlling step. Furthermore, during CR adsorption on 003 sites, adsorption kinetics was diffusion-controlled.
\end{abstract}

Keywords: Mg-Al-LDH; Congo red; Adsorption; ARIAN model; KASRA model; ISO equation

\section{Introduction}

Discharge of wastewater produced by industries is a main source of water pollution. These pollutants of the discharged wastewater are harmful to environment and human and animal health. Dye substances are one detrimental group of these pollutant compounds. ${ }^{1}$ Large amounts of effluents containing dye compounds are generated by industries that produce paper, ${ }^{2}$ textiles, ${ }^{3}$ rubber, ${ }^{4}$ food, ${ }^{5}$ cosmetics $^{6}$ and leather. ${ }^{7}$ Various chemical, physical and biological methods are used to remove pollutants from wastewaters. Some of these methods are biological degradation, ${ }^{8}$ coagulation/flocculation, ${ }^{9}$ membrane separation, ${ }^{10}$ chemical oxidation, ${ }^{11}$ ion exchange ${ }^{12}$ and adsorption. ${ }^{13}$ Among these methods, adsorption is a suitable candidate for dye removal due to its simplicity, high adsorption capacity and non-toxicity.

Congo red (CR), the sodium salt of 3,3'-([1,1'-biphenyl]-4,4'-diyl)bis(4-aminonaphthalene-1-sulfonic acid), is a benzidine-based diazo anionic dye. ${ }^{14} \mathrm{CR}$ is used as an acid-base indicator and for staining tissues in histology and microscopy. ${ }^{15}$ It is mainly used for dyeing cotton, hemp, silk and paper products. ${ }^{16}$ However, it is known to be carcinogenic. ${ }^{17}$ Moreover, due to its complex structure, it is very stable to biological degradation and remains in the environment for a long period of time. ${ }^{18}$

For removing CR from effluents, different types of adsorbents like activated carbon, ${ }^{19}$ shrimp shell powder, ${ }^{20}$ mesoporous $\alpha-\mathrm{Fe}_{2} \mathrm{O}_{3}$ nanorods, ${ }^{21}$ nano- $\mathrm{Fe}_{3} \mathrm{O}_{4},{ }^{22}$ kaolin, ${ }^{23}$ hydroxyapatite ${ }^{24}$ and biogas waste slurry ${ }^{25}$ have been used.

Layered double hydroxides (LDHs) or anionic clay or hydrotalcite-like compounds are natural or synthetic lamellar hydroxides. There are two types of metallic cations in their main layers and hydrated interlayer domains containing anionic species. ${ }^{26,27}$ The general formula of LDHs is $\left[\mathrm{M}^{2+}{ }_{1-\mathrm{x}}, \mathrm{M}^{3+}{ }_{\mathrm{x}}(\mathrm{OH})_{2}\right]^{\mathrm{x}+}(\mathrm{A})^{\mathrm{n}-}{ }_{\mathrm{x} / \mathrm{n}} \cdot \mathrm{mH}_{2} \mathrm{O}$, where the $\mathrm{M}^{2+}$ and $\mathrm{M}^{3+}$ cations occupy the octahedral holes in a brucite-like layer surrounded by $\mathrm{OH}$ groups. The water and $\mathrm{A}^{\mathrm{n}-}$ anions are in the interlayer spaces which $\mathrm{A}^{\mathrm{n}-}$ anions balance the positive charge of $\mathrm{M}^{3+}$ cations in the layers. ${ }^{28,29}$ LDHs are synthesized simply and have a high anion exchange capacity. The optical, thermal and mechanical properties of nanocomposites of $\mathrm{LDH}$ and polymers were improved compared to those of neat polymers. ${ }^{30,31}$ Also, LDHs are used as ion-exchange mineral, ${ }^{32}$ adsorbent, ${ }^{33}$ catalysts $^{34,35}$ and coatings to protect metallic alloys. ${ }^{36,37}$

In this work, the synthesized Mg-Al-LDH nanocompound was characterized by different methods, like SEM, 
BET, FTIR and XRD. The adsorption capacity of LDH for $\mathrm{CR}$ was measured under different experimental variables like $\mathrm{CR}$ concentration, $\mathrm{pH}$, contact time, temperature, shaking rate and ionic strength. Adsorption mechanism of CR was studied by analysis of thermodynamics and kinetics of this adsorption process using the ARIAN and KASRA models respectively. These models made possible surveying adsorption isotherms and kinetic curves.

\section{Experimental}

\section{1. Chemicals}

Aluminum nitrate $\left(\mathrm{Al}\left(\mathrm{NO}_{3}\right)_{3} \cdot 9 \mathrm{H}_{2} \mathrm{O}\right)$, magnesium nitrate $\left(\mathrm{Mg}\left(\mathrm{NO}_{3}\right)_{2} \cdot 6 \mathrm{H}_{2} \mathrm{O}\right)$, sodium hydroxide, sodium carbonate, hydrochloric acid, sodium chloride and congo red were purchased from Merck. All chemicals were used without further purification.

\section{2. Synthesis of Mg-Al-LDH}

$\mathrm{Mg}-\mathrm{Al}-\mathrm{LDH}$ was synthesized based on the published procedure. $^{38} 5.32 \mathrm{~g}$ of aluminum nitrate and $11.534 \mathrm{~g}$ of magnesium nitrate $(\mathrm{Mg} / \mathrm{Al}$ molar ratio is $2 / 1)$ were dissolved in $60 \mathrm{ml}$ of distilled water (Solution A). Similarly, $4.8 \mathrm{~g}$ sodium hydroxide and $1.05 \mathrm{~g}$ sodium carbonate were dissolved by adding $60 \mathrm{ml}$ of distilled water (Solution B). Then, the Solution B was added dropwise to Solution A while stirring at $300 \mathrm{rpm}$. The $\mathrm{pH}$ of mixture was monitored by a $\mathrm{pH}$ meter. After adding Solution $\mathrm{B}$ to the Solution $\mathrm{A}$ the final $\mathrm{pH}$ of mixture was 10 . Afterwards, the resulting slurry was kept stirring at $300 \mathrm{rpm}$ and the mouth of container was sealed by a single layer of Parafilm ${ }^{\circ}$. The container was subsequently heated at $60^{\circ} \mathrm{C}$ in an oil bath for $24 \mathrm{~h}$. Then distilled water was added to precipitate $\mathrm{Mg}$ Al-LDH. The LDH solid was separated from its supernatant by a centrifuge at $6000 \mathrm{rpm}$. This washing process was repeated 5 times and finally the participate was dried at room temperature.

\section{3. Characterization of Mg-Al-LDH}

The crystal structure of synthesized carbonate intercalated Mg-Al-LDH was characterized by a Rigaku D-max $\mathrm{C}$ III, X-ray diffractometer (XRD) using Ni-filtered $\mathrm{Cu}-\mathrm{Ka}$ radiation $(\lambda=1.5406 \AA)$. As shown in Fig. 1(a), XRD pattern of Mg-Al-DH showed a typical layered structure of Mg-Al-LDH $\left(\mathrm{Mg}_{6} \mathrm{Al}_{2}(\mathrm{OH})_{16} \mathrm{CO}_{3} \cdot 4 \mathrm{H}_{2} \mathrm{O}\right)$ with peaks at $11.6^{\circ}$ and $23.1^{\circ}$ corresponding to (003) and (006) planes of the Mg-Al-LDH phase. The interlayer distances $\mathrm{d}_{003}$ and $\mathrm{d}_{006}$ were 0.76 and $0.38 \mathrm{~nm}$ respectively which were consistent with published papers. ${ }^{36}$

This information showed that the Mg-Al-LDH nanocompound with carbonate anions in the interlayer had been synthesized successfully. ${ }^{39}$ The average size of $\mathrm{Mg}$ Al-LDH particles, estimated by Debye-Scherrer formu-

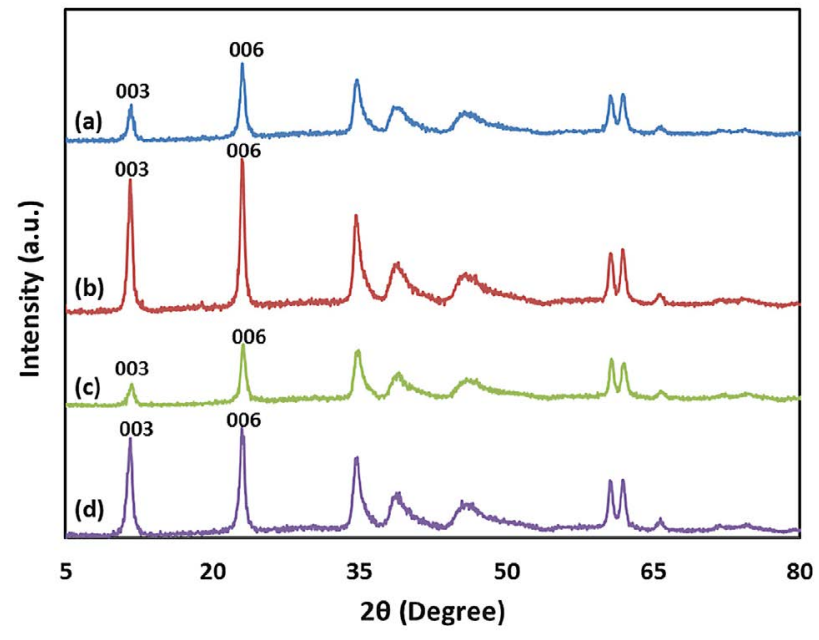

Figure 1. XRD spectra of (a) Mg-Al-LDH, (b) CR-adsorbed Mg-AlLDH, (c) Mg-Al-LDH modified with $\mathrm{NaOH}$ solution at $\mathrm{pH}=10$ and (d) Mg-Al-LDH modified with $\mathrm{NaOH}$ solution at $\mathrm{pH}=13$.

la, ${ }^{36}$ was about $65 \mathrm{~nm}$. Also, XRD spectra of CR-adsorbed $\mathrm{Mg}-\mathrm{Al}-\mathrm{LDH}$ and $\mathrm{Mg}-\mathrm{Al}-\mathrm{LDH}$ modified with alkaline solutions, Figs. 1(b)-1(d), were similar to the XRD spectrum of pristine $\mathrm{Mg}$-Al-LDH. ${ }^{39}$

IR spectra of Mg-Al-LDH were taken by a Nicolet IR 100 (Thermo Scientific) FTIR spectrophotometer using $\mathrm{KBr}$ pellet technique, Fig. 2(a). The bands at 3532.9 and $1643.1 \mathrm{~cm}^{-1}$ in the IR spectrum of pristine $\mathrm{Mg}-\mathrm{Al}-\mathrm{LDH}$ were assigned to the stretching vibration of interlayer $-\mathrm{OH}$ groups of $\mathrm{Mg}-\mathrm{Al}-\mathrm{LDH}$ nanocompound and water mole-

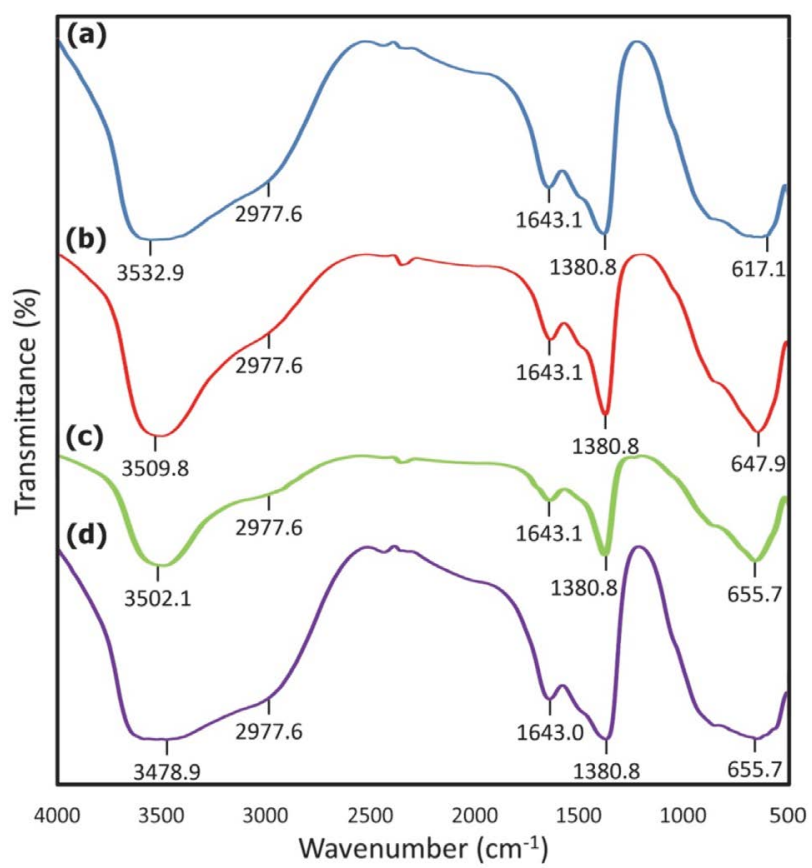

Figure 2. IR spectra of (a) Mg-Al-LDH, (b) CR-adsorbed Mg-Al$\mathrm{LDH}$, (c) Mg-Al-LDH modified with $\mathrm{NaOH}$ solution at $\mathrm{pH}=10$ and (d) Mg-Al-LDH modified with $\mathrm{NaOH}$ solution at $\mathrm{pH}=13$. 
cules adsorbed on Mg-Al-LDH surface, respectively. ${ }^{39-41}$ The peaks at 1380.8 and $617.1 \mathrm{~cm}^{-1}$ and the shoulder at $2977.6 \mathrm{~cm}^{-1}$ were attributed correspondingly to the $\mathrm{C}-\mathrm{O}$ stretching mode of carbonate group, $\mathrm{Al}-\mathrm{O}$ stretching mode and stretching vibration of carbonate $-\mathrm{H}_{2} \mathrm{O}$ in the interlayer. ${ }^{36,42,43}$

Scanning electron micrographs of Mg-Al-LDH were taken using a MIRA3 TESCAN instrument at $15 \mathrm{keV}$. SEM photos indicated that the surface morphology of Mg-AlLDH nanocompound and its samples modified with $\mathrm{NaOH}$ solutions at $\mathrm{pHs}$ of 10,13 and 14 were aggregation of Mg-Al-LDH particles with a sand rose morphology, Figs. 3(a)-3(d). It seemed that after neutralization reaction of -OH groups of $\mathrm{Mg}$-Al-LDH nanocompound with $\mathrm{NaOH}$ at alkaline solutions, Figs. 3(b)-3(d), repulsion interaction between resulted $-\mathrm{O}^{-}$groups of these particles made changes in the morphology of adsorbent.

EDS (Energy Dispersive X-Ray Spectroscopy) spectrum of the synthesized Mg-Al-LDH nanocompound was prepared by a MIRA3 TESCAN instrument.
The results showed that atomic percentages of magnesium and aluminum on its surface were 18.88 and $6.62 \%$ respectively which validated the $\mathrm{Mg}-\mathrm{Al}-\mathrm{LDH}$ formation, Fig. 4.

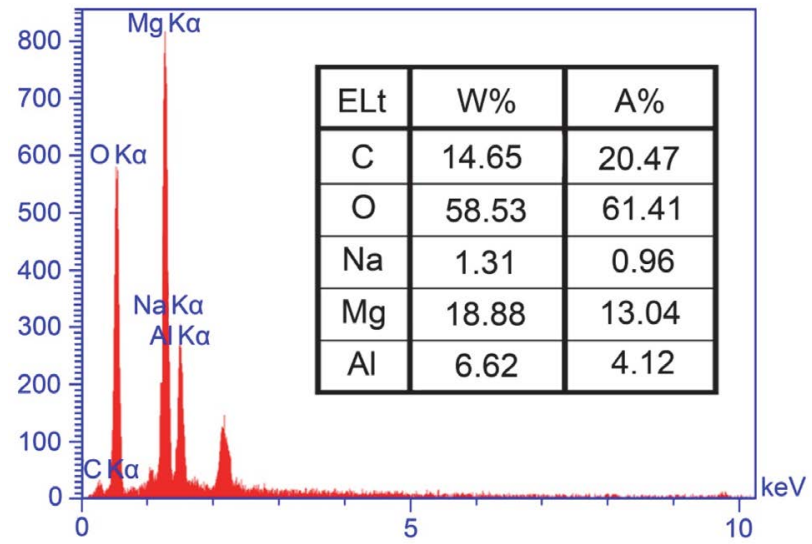

Figure 4. EDS spectrum of Mg-Al-LDH nanocompound.
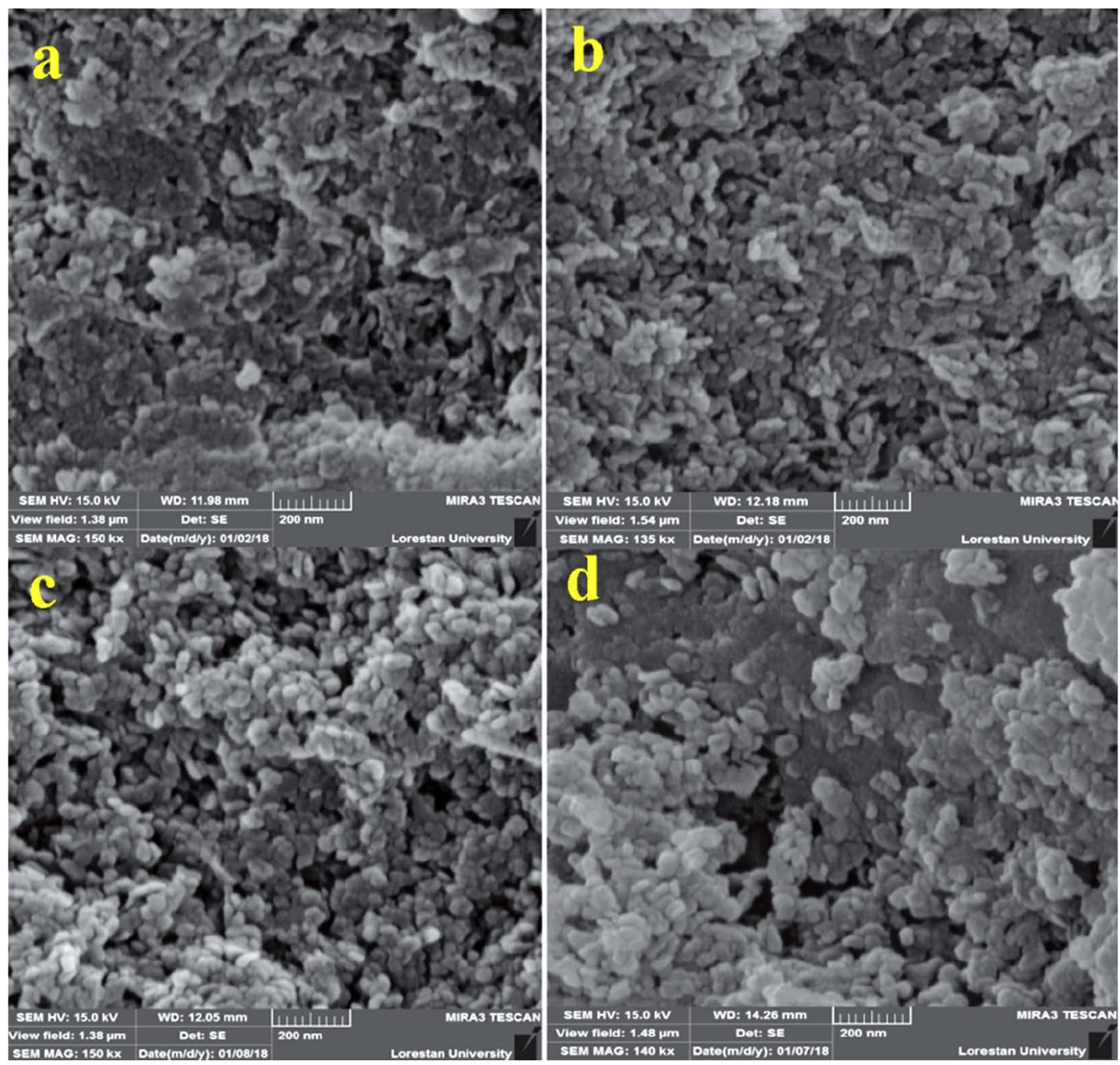

Figure 3. SEM images of (a) Mg-Al-LDH and Mg-Al-LDH modified with $\mathrm{NaOH}$ solutions at pHs of (b) 10, (c) 13 and (d) 14 . 
Also, EDS spectra of the CR-adsorbed Mg-Al-LDH sample and $\mathrm{Mg}$-Al-LDH modified with $\mathrm{NaOH}$ solutions at pHs of 10, 12 and 13 showed small differences with pure $\mathrm{Mg}-\mathrm{Al}-\mathrm{LDH}$ nanocompound, Figs. 4 and S1(a)-(c).

The nitrogen-based BET specific surface areas of $\mathrm{Mg}-\mathrm{Al}-\mathrm{LDH}$ and Mg-Al-LDH modified with a $\mathrm{NaOH}$ solution of $\mathrm{pH}=13$ for 3 hours and after adsorption of CR in a neutral solution were measured by a Pore Size Micrometrics-tristar 3020 equipment, Figs. S2(a)-(c). These isotherms were Type IV and were implied that Mg-Al-LDHs are porous materials. Nitrogen molecules were condensed in the tiny adsorbent capillary mesopores and micropores. The BET surface area, adsorption average pore diameter (by BET), pore volume and micropore volume were 112.83 $\mathrm{m}^{2} \mathrm{~g}^{-1}, 22.6 \mathrm{~nm}, 0.64 \mathrm{~cm}^{3} \mathrm{~g}^{-1}$ and $0.012 \mathrm{~cm}^{3} \mathrm{~g}^{-1}$ for Mg-Al$\mathrm{LDH}, 89.45 \mathrm{~m}^{2} \mathrm{~g}^{-1}, 24.1 \mathrm{~nm}, 0.54 \mathrm{~cm}^{3} \mathrm{~g}^{-1}$ and $0.009 \mathrm{~cm}^{3}$ $\mathrm{g}^{-1}$ for Mg-Al-LDH at $\mathrm{pH}=13$ and $101.75 \mathrm{~m}^{2} \mathrm{~g}^{-1}, 22.4 \mathrm{~nm}$, $0.57 \mathrm{~cm}^{3} \mathrm{~g}^{-1}$ and $0.015 \mathrm{~cm}^{3} \mathrm{~g}^{-1}$ for CR-adsorbed Mg-AlLDH sample, respectively. Results showed that the most of pores were mesopore (with an average diameter of $23 \mathrm{~nm}$ ) and a small part of them were micropore and also verified that CR molecules were adsorbed on the mesopore and interlayer micropore sites and also the neutralization of interlayer $-\mathrm{OH}$ groups decreased adsorbent surface area. The hysteresis loop of these three BET isotherms were H1 which was ascribed to agglomerates or spherical particles in a cylindrical pore geometry, indicating relatively high pore size uniformity and facile pore connectivity. ${ }^{45}$

\section{4. Adsorption Studies}

\section{4. 1. Adsorption Experiments}

The adsorption experiments were carried out in a series of 10 - $\mathrm{ml}$ glass bottles. $0.0025 \mathrm{~g}$ of adsorbent (Mg- $\mathrm{Al}$ $\mathrm{LDH}$ ) was added to each bottle and then charged with 10 $\mathrm{ml}$ of CR solution with a certain initial concentration. The bottles were shaken at $100 \mathrm{rpm}$ in a temperature controlled shaking water bath (Fater electronic Co., Persian Gulf model) at 308,318 and $328 \mathrm{~K}$ within $\pm 0.1 \mathrm{~K}$ for $6 \mathrm{~h}$ to reach equilibrium. The initial concentration ranges of $\mathrm{CR}$ were 3 $\times 10^{-6}-10^{-4} \mathrm{M}$. After adsorption, the CR concentration in each bottle was determined by photometry (UV mini $1240 \mathrm{~V}$, Shimadzu) at their $\lambda_{\max }$ values in these solutions. The $\lambda_{\max }$ value of CR in water was $489 \mathrm{~nm}$. The CR adsorption capacity on the adsorbent, $q_{e}\left(\mathrm{mg} \mathrm{g}^{-1}\right)$, was calculated as follows

$$
q_{e}=\frac{\left(c_{0}-c_{e}\right) M v}{1000 w}
$$

where $c_{0}$ and $c_{e}$ are the initial and equilibrium concentrations of adsorbate in each solution (M) respectively, $v$ is the volume of solution $(\mathrm{ml}), w$ is the weight of the used adsorbent $(\mathrm{g})$ and $M$ is the molecular weight of adsorbate (mg mole ${ }^{-1}$ ).

In adsorption kinetic experiments, $0.0025 \mathrm{~g}$ samples of Mg-Al-LDH were added to a series of bottles including
$10 \mathrm{ml}$ of CR solutions with initial concentrations $\left(10^{-5}, 6 \times\right.$ $10^{-5}$ or $\left.9 \times 10^{-5} \mathrm{M}\right)$. The solutions were shaken at 30,70 and $100 \mathrm{rpm}$ and at 308,318 and $328 \mathrm{~K}$. At determined contact times, the concentrations of CR in the solutions were measured by photometry at their $\lambda_{\max }$ values. In this type of experiments, $q_{e}$ and $c_{e}$ in Eq. (1) were replaced by $q_{t}$ (adsorption capacity at time $t$ ) and $c_{t}$ (concentration of adsorbate at time $t$ ), respectively.

\section{4. 2. Adsorption Thermodynamic Isotherms and Models}

The adsorption isotherms were studied by "a $\underline{a}$ sorption isotherm regional analysis model" or abbreviated as the ARIAN model. ${ }^{46,47}$ It is good to say that ARIAN is a Persian word meaning Iranian. This model has been introduced for studying adsorption isotherms up to four regions. In the ARIAN model, it is assumed that region I obeys the Henry's law:

$$
q_{e}=K c_{e}
$$

where $K$ is the binding constant of adsorbate on the surface and adsorption increases linearly with concentration. Region II starts from the starting second region concentration (abbreviated as ssc) point. In this region only monolayer adsorption occurs and can be studied by an appropriate isotherm such as the Langmuir and Temkin equations and etc. The linearized form of the Langmuir equation ${ }^{48}$ is represented as

$$
\frac{c_{e}}{q_{e}}=\frac{1}{q_{\max } K}+\frac{c_{e}}{q_{\max }}
$$

where $q_{\max }$ is the monolayer capacity of adsorbent and $K$ is the Langmuir adsorption equilibrium constant. The Temkin equation ${ }^{49}$ is given by

$$
q_{e}=c_{1} \ln \left(c_{2} c_{e}\right)
$$

where $c_{1}$ is a constant and $c_{2}$ is adsorption equilibrium constant.

In region III, new surface aggregates of molecules (or admicelles) and new surface clusters (in the case of surfactants) form. The starting third region concentration (abbreviated as $s t c$ ) point defines the beginning of this region. The bilayer isotherm, Eq. (5), and those derived from it, Eqs. (6) and (7) are used for analysis of data of this region. ${ }^{46}$ In region III, by assuming adsorption occurs mostly in the first and second layers, we have

$$
\frac{c_{e}}{q_{e}}=\frac{1+c_{e} K_{s a}+x c_{e}^{2} K_{s a}}{q_{\text {mon }} K_{s a}+2 q_{\text {mon }} x c_{e} K_{s a}}
$$

where $q_{\text {mon }}$ and $q_{e}$ are the monolayer and equilibrium adsorption capacity, respectively. $K_{s a}$ and $x$ are the adsorption equilibrium constants of adsorbate molecules in the first layer surface aggregates and that of adsorbate mole- 
cules in all layers excluding the first layer, respectively. If adsorbate molecules are adsorbed mostly on the first layer, ${ }^{46}$ Eq. (5) can be written as

$$
\frac{c_{e}}{q_{e}}=\frac{1}{q_{m o n} K_{s a}}+\frac{c_{e}}{q_{\text {mon }}}+\frac{x c_{e}^{2}}{q_{m o n}}
$$

which is used for surface low bilayer coverage (abbreviated as LBC isotherm) and if the adsorption process results in the formation of a monolayer, ${ }^{46} \mathrm{Eq}$. (5) is reduced to

$$
\frac{c_{e}}{q_{e}}=\frac{1}{q_{m o n} K_{s a}}+\frac{c_{e}}{q_{m o n}}
$$

where Eq. (7) is a Langmuir-type equation. The region IV starts where the adsorption capacity reaches the maximum, showing a plateau on the isotherm, or where the isotherm begins to go down. The second situation in region IV is called the reverse desorption and obeys from the reverse desorption equation. ${ }^{46}$ Depending upon the adsorbate and adsorption sites characteristics, two or more sub-regions in each of regions II or III or IV may be observed in an adsorption isotherm. Each of these sub-regions are called a section and to discriminate between them, they are denoted using English capital letters and written as IIA, IIB etc.

Also, in some cases, due to some factors like repulsion interaction between adsorbate-adsorbed surface and free adsorbate molecules, adsorption process is stopped in a certain adsorbate concentration range. ${ }^{50}$ This adsorbate concentration range is called CRAC. CRAC is an abbreviation for "concentration range of leveling off between two successive adsorption isotherm curves". Schematic adsorption isotherm of CR on Mg-Al-LDH according to the ARIAN model was shown in Fig. 5.

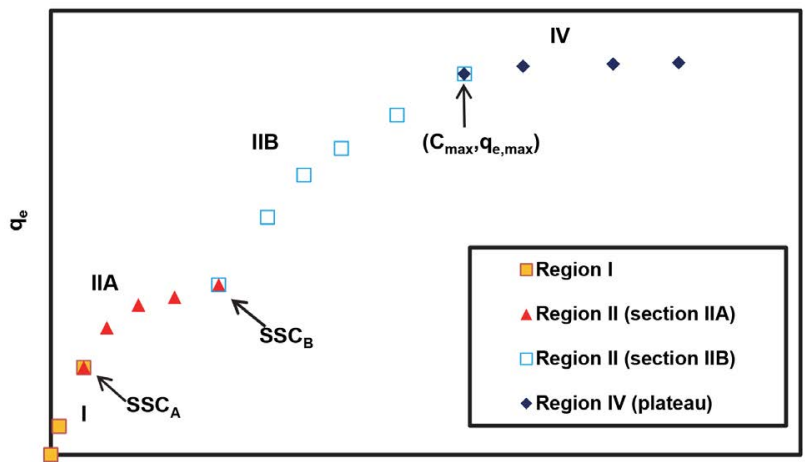

Ce

Figure 5. Typical adsorption isotherms of CR on Mg-Al-LDH nanocompound. Different regions according to the ARIAN model are shown in the diagram.

\section{4. 3. Adsorption Kinetic Equations and Models}

The kinetic data were analyzed by several equations. The intraparticle diffusion equation ${ }^{51}$ is shown as:

$$
q_{t}=k_{d i f} t^{0.5}+I
$$

Where $k_{d i f}$ is the rate constant for intraparticle diffusion and $I$ is proportional to the boundary layer thickness.

Also, the KASRA model and KASRA equation ${ }^{47,52,53}$ were used to analyze the adsorption kinetics. KASRA is an abbreviation for "kinetics of adsorption study in the regions with constant adsorption acceleration" and is a synonym of "king" in Persian. The KASRA model is based on the following assumptions: (1) each time range that adsorption acceleration in it is constant, is named a "region", (2) there are two regions before reaching the plateau region, and (3) the boundaries between the first and second regions and the second and third (plateau) regions are named starting second region (abbreviated as ssr) point and kinetics of a $\underline{d}$ sorption termination (abbreviated as kat) point, respectively. Both $s s r$ and kat points are determined by the KASRA equation ${ }^{52}$ given as follows:

$q_{t}=\frac{1}{2} a_{i} t^{2}+\left(v_{0 i}-a_{i} t_{0 i}\right) t+q_{0 i}-\frac{1}{2} a_{i} t_{0 i}^{2}-\left(v_{0 i}-a_{i} t_{0 i}\right) t_{0 i}$

Where $q_{0 i}, v_{0 i}$ and $t_{0 i}$ are $q_{t}$, velocity and time at the beginning of the ith region, respectively, $a_{i}$ is the acceleration of adsorption kinetics in the $i$ th region whereas $i=1-3$. Each $a_{i}$ is a negative value because of the decrease in the adsorbate concentration during adsorption process. In the first region, $t_{01}$ and $q_{01}$ are equal to zero. The second region starts from ssr point which is assigned with the coordinates $t_{02}$ and $q_{02}$. Finally, plateau (third) region begins at the equilibrium time, $t_{e}$ and equilibrium adsorption capacity, $q_{e}$ which are coordinates of kat point. In this region, $v_{03}=a_{3}=$ $0, t_{03}=t_{e}$ and $q_{03}=q_{e}$ and Eq. (9) is simplified to $q_{t}=q_{e}$. Due to different features of the first and second regions, parameters obtained for these two regions such as rate constants are different from each other and the related equations for these regions come different pathways from the point $q_{t}=0$ at $t=0$.

In this work, to avoid confusion in relation to the regions in isotherms and kinetic curves, kinetic regions are shown using numbers like region 1 and etc. A schematic adsorption kinetic curve of CR on Mg-Al-LDH according to the KASRA model was shown in Fig. 6.

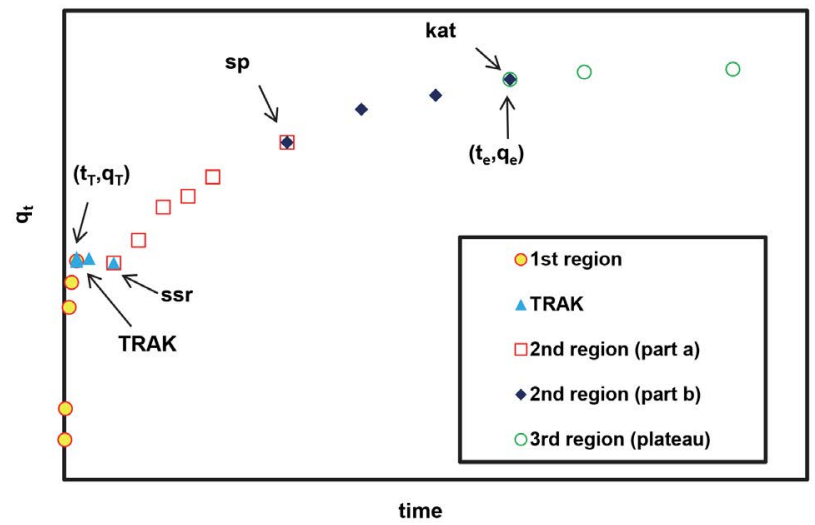

Figure 6. Typical bi-curve adsorption kinetic diagram of CR adsorption on Mg-Al-LDH. Different regions according to the KASRA model are shown in the diagram. 
The ideal-second-order (or abbreviated as ISO) equation $^{47,54}$ is shown as

$$
\ln \left(\frac{q_{e}-q_{t}}{a c_{t}}\right)=-\frac{k_{I} c_{e}}{q_{e}} t+A^{\prime}
$$

where $k_{I}=k_{I}^{2} q_{e}$ [53] and $k_{I}^{2}$ are the first- and second-order adsorption rate constants of the ISO equation in each region and are in $\mathrm{M}^{-1} \mathrm{mg} \mathrm{g}^{-1} \mathrm{~min}^{-1}$ and $\mathrm{M}^{-1} \mathrm{~min}^{-1}$, respec-

tively and $A^{\prime}=\ln \left(\frac{q_{e}}{a c_{0}}\right) \cdot a=\frac{M v}{1000 w}$, where $v$ is the volume of solution $(\mathrm{ml}), w$ is the weight of the used adsorbent $(\mathrm{g})$ and $M$ is the molecular weight of adsorbate (mg $\left.\mathrm{mole}^{-1}\right)$. Some adsorbents have $m$ different adsorption sites and adsorption occurs in sequence on their first, then second, . . ., $(m-1)$ th and $m$ th sites respectively. In these cases, there are $m$ kinetic curves and in Eq. (10) $q_{e}$ and $c_{e}$ are used for $m$ th site and for $m-1$ other sites these symbols are replaced with $q_{t, \max }^{i}$ and $c_{t, \max }$, where $i=1, \ldots m$ - 1. $q_{t, \text { max }}^{i}$ and $c_{t, \text { max }}^{i}$ are the maximum adsorption capacity of adsorbent and adsorbate concentration after absorption completion on the ith adsorption site, respectively. Thus, the ISO equation is used $m$ times to analyze these $m$ kinetic curves. ${ }^{50,54}$

As referred before, based on the KASRA model, there are two regions in adsorption kinetic curves before reaching the plateau which result from non-ideality in adsorption. In the first one, completely ideal adsorption occurs on the bare surface of adsorbent. The progressively changes occurred on the surface of adsorbent in region 1 finally result in emerging another ideal region (region 2) in which adsorption carries out on a partly adsorbate-covered surface. Using the ISO equation shows that region 2 is composed of two another ideal parts that are named $2 \mathrm{a}$ and $2 \mathrm{~b}$. The first part of the second region, $2 \mathrm{a}$, starts after ss $r$ point and the second one, $2 \mathrm{~b}$, starts after starting second part (or abbreviated as $s p$ ) point and ends at the kat point. ${ }^{50,54}$

The ISO first-order rate constant of region 1 is shown with $k_{I 1}$ and those of the second region are shown with $k_{I 2 a}$ and $k_{I 2 b}$. Also, the ISO second-order rate constant of region 1 is shown with $k_{I 1}^{2}$ and those of the second region are shown with $k_{I 2 a}^{2}$ and $k_{I 2 b}^{2}$. As referred, in some adsorbents, there are two or more different adsorption sites which result in observing two or more successive adsorption kinetic curves in adsorption kinetic diagram. In these cases, region 1 , (completely ideal) is only observed in the first adsorption kinetic curve, Fig. $6 .^{54}$

Sometimes, due to braking effect ${ }^{50}$ an interval is observed between two successive adsorption kinetic curves or between regions 1 and 2 of the first adsorption curve. The "time range of interval between two successive adsorption kinetic curves" (abbreviated as TRAK) is used to compare this effect in different cases. ${ }^{50}$ On the other hand, the initial concentration of adsorbate has an important role in appearing the TRAK in an adsorption kinetic curve. Thus, for comparing kinetic curves including TRAK(s) with together and other kinetic curves, their first-order rate constants obtained from the ISO equation are used. Also in some cases, due to some factors like repulsion interaction between adsorbent surface and adsorbate, it takes time for adsorption process to occur and then region 1 starts with time delay. In this work, this time period is named $T D$ which is an abbreviation for "Time Delay". If adsorption results in a TRAK, $q_{t, \text { max }}$ and $c_{t, \text { max }}$ are replaced by $q_{T}^{n}$ and $c_{T}^{n}$, respectively. $q_{T}^{n}$ and $c_{T}^{n}$ are adsorption capacity of adsorbent and adsorbate concentration at the beginning of the TRAK between $n$th and $(n+1)$ th kinetic curves, respectively. In these cases, $k_{I}=k_{I}^{2} q_{T}^{n}$ and subscript $T$ is an abbreviation for TRAK. ${ }^{53}$

\section{Results and Discussion}

\section{1. Thermodynamics of Adsorption of CR on Mg-Al-LDH in Neutral Aqueous Solutions}

Using adsorption experimental isotherms and models is a very important tool to elucidate the mechanism of an adsorption process. In this study, $\mathrm{Mg}-\mathrm{Al}-\mathrm{LDH}$ nanocompound was used as the adsorbent for CR molecules. Analysis of results by the ARIAN model showed that isotherms of this process composed of regions I and II and finally reached to region IV (plateau), Figs. 5 and 7 and Tables 1-3. Here, region II was formed from two sections that based on the nomenclature used in the ARIAN model were shown as sections IIA and IIB.

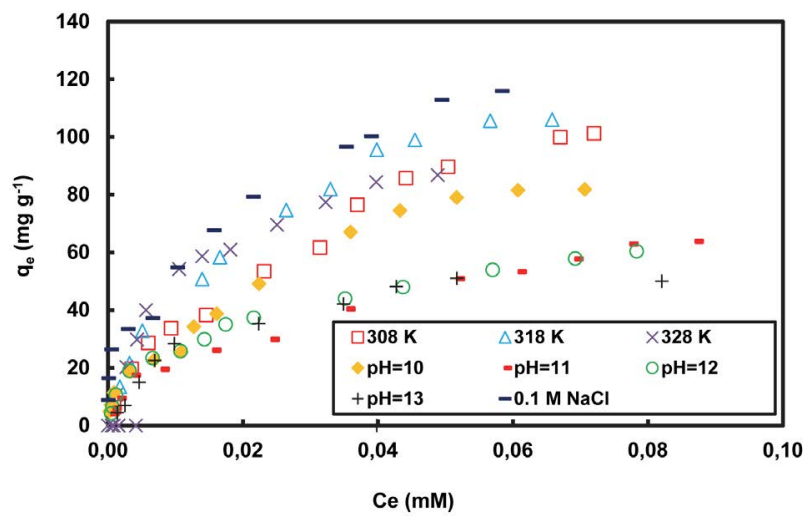

Figure 7. $q_{e}$ vs. $c_{e}$ for adsorption of CR on Mg-Al-LDH nanocompound from neutral aqueous solutions at $308-328 \mathrm{~K}$ and from alkaline and $0.1 \mathrm{M} \mathrm{NaCl}$ solutions at $318 \mathrm{~K}$.

As shown in Fig. 8, hydrogen atoms of $-\mathrm{OH}$ groups attached to $\mathrm{Al}$ atoms of $\mathrm{LDH}$ layers were the adsorption sites for negatively charged oxygen atoms of sulfonate groups and delocalized electrons of CR molecules.

As seen in Fig. 1(a), XRD spectra of Mg-Al-LDH, peak at $11.6^{\circ}$ corresponding to the basal spacing distances 
a)

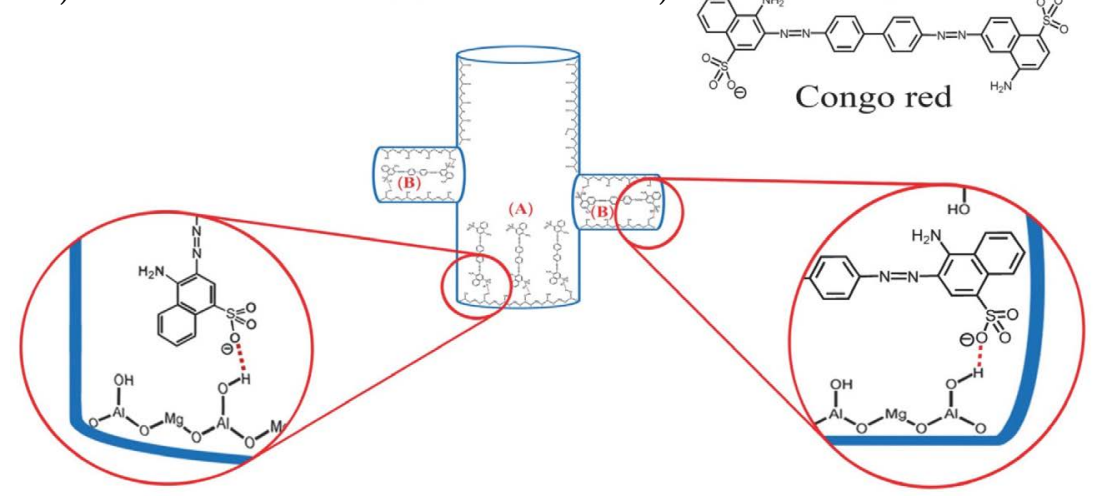

Figure 8. (a) Schematic representation of (A) MP and (B) 003 adsorption sites of Mg-Al-LDH and (b) CR molecule structure.

$\mathrm{d}_{003}$ was equal to $0.76 \mathrm{~nm}$ and classified as micropore. Furthermore, comparison of data of nitrogen-based BET specific surface area tests for average pore diameter for $\mathrm{Mg}$-Al$\mathrm{LDH}$ and CR-adsorbed $\mathrm{Mg}$-Al-LDH showed that CR molecules adsorbed on the mesopores didn't occupy the pore apertures. On the other hand, the width and length of $\mathrm{CR}$ molecule were 0.7 and $2.5 \mathrm{~nm}$, respectively and thus were less than interlayer distance of (003) indexed brucite-like planes. Therefore, the two kinds of adsorption sites involved in the adsorption process were -OH groups placed in the micropores between (003) planes with $0.76 \mathrm{~nm}$ interlayer distance and $-\mathrm{OH}$ groups located in the mesopores. The former adsorption site was denoted as 003 and the latter one defined as mesopore (abbreviated as MP) adsorption sites. Based on the size of pores, CR molecules at first interacted with MP sites and then by penetration into the interlayer galleries of 003 layers interacted with 003 sites.

Data obtained from analysis of adsorption isotherms at different temperatures were shown in Tables 1-3. To calculate the thermodynamic parameters of region I, section IIA and section IIB the binding constants obtained from the Henry, Temkin and Temkin isotherms were used, respectively.
As seen in Table 1, the adsorption binding constants of $\mathrm{CR}$ to the most active MP adsorption sites in region I at different temperatureswere comparable and the process was slightly endothermic and $\Delta H$ and $\Delta S$ values of the process in this region were $9.3 \mathrm{~kJ} \mathrm{~mol}^{-1}$ and $-70.4 \mathrm{~J} \mathrm{~mol}^{-1}$ $\mathrm{K}^{-1}$, respectively. But, the adsorption of CR on less active MP sites in section IIA was exothermic and $\Delta H$ and $\Delta S$ values of the process in this region were $-32.4 \mathrm{~kJ} \mathrm{~mol}^{-1}$ and $14.2 \mathrm{~J} \mathrm{~mol}^{-1} \mathrm{~K}^{-1}$, respectively, Table 2 .

In region I, CR molecules were adsorbed on the bare surface of adsorbent. In section IIA, CR molecules were adsorbed on adsorption sites nearby adsorbed CR molecules and due to spatial hindrance and negative charge of formerly adsorbed CR molecules adsorption in section IIA was exothermic.

On the other hand, adsorption binding constants to 003 site in section IIB at different temperatures were smaller than those in section IIA and the process was endothermic and $\Delta H$ and $\Delta S$ values of the process in this region were $50.8 \mathrm{~kJ} \mathrm{~mol}^{-1}$ and $262.9 \mathrm{~J} \mathrm{~mol}^{-1} \mathrm{~K}^{-1}$, respectively, Table 3 .

Direction of adsorbed CR molecules in 003 sites depended on the distance between Mg-Al-LDH layers. ${ }^{41} \mathrm{It}$

Table 1. Parameters obtained from the Henry's law an $s s c_{A}$ and $q_{s s c A}$ values for adsorption of $\mathrm{CR}$ on $\mathrm{Mg}-\mathrm{Al}-\mathrm{LDH}$ nanocompound in water and $0.1 \mathrm{M} \mathrm{NaCl}$ solutions in region I (on MP site) at $308-328 \mathrm{~K}$.

\begin{tabular}{lcccccc}
\hline Solvent & $\begin{array}{c}\mathbf{T} \\
(\mathbf{K})\end{array}$ & $\boldsymbol{A}$ & $\begin{array}{c}\text { Henry's law } \\
\boldsymbol{K}\end{array}$ & $\boldsymbol{R}^{\mathbf{2}}$ & $\begin{array}{c}\boldsymbol{s s c}_{\boldsymbol{A}} \\
(\mathbf{m M})\end{array}$ & $\begin{array}{c}\boldsymbol{q}_{\boldsymbol{s s c A}} \\
\left(\mathbf{m g ~ g}^{\mathbf{- 1}}\right)\end{array}$ \\
\hline Water & 308 & 0.66 & $5.48 \times 10^{6}$ & 0.99 & $3.51 \times 10^{-3}$ & 19.7 \\
& 318 & 1.00 & $6.66 \times 10^{6}$ & 0.98 & $3.18 \times 10^{-3}$ & 21.6 \\
& 328 & 1.22 & $6.82 \times 10^{6}$ & 0.99 & $4.30 \times 10^{-3}$ & 29.8 \\
$0.1 \mathrm{M} \mathrm{NaCl}$ & 318 & 0.19 & $1.65 \times 10^{8}$ & 0.99 & $9.99 \times 10^{-5}$ & 16.4 \\
$\mathrm{pH}=10$ & 318 & 0.15 & $1.79 \times 10^{7}$ & 0.98 & $4.07 \times 10^{-4}$ & 7.2 \\
$\mathrm{pH}=11$ & 318 & 0.09 & $6.99 \times 10^{6}$ & 0.98 & $8.61 \times 10^{-4}$ & 6.0 \\
$\mathrm{pH}=12$ & 318 & -0.09 & $9.89 \times 10^{6}$ & 0.99 & $6.47 \times 10^{-4}$ & 6.6 \\
pH $=13$ & 318 & 0.20 & $2.78 \times 10^{6}$ & 0.99 & $2.51 \times 10^{-3}$ & 6.9 \\
\hline
\end{tabular}

Dimensions of $A$ and $K$ are in $\mathrm{mg} \mathrm{g}^{-1}$ and $\mathrm{mg} \mathrm{g}^{-1} \mathrm{M}^{-1}$, respectively. Henry's law for experimental data is as $q_{e}=K c_{e}+A$ 
Table 2. Parameters obtained from the Temkin and Langmuir equations and $s c_{B}$ and $q_{s s c B}$ values for adsorption of CR on Mg-Al-LDH nanocompound in water, $0.1 \mathrm{M} \mathrm{NaCl}$ and alkaline solutions in section IIA (on MP site) at $308-328 \mathrm{~K}$.

\begin{tabular}{|c|c|c|c|c|c|c|c|c|c|}
\hline \multirow[t]{2}{*}{ Solvent } & \multirow{2}{*}{$\begin{array}{c}\mathbf{T} \\
(\mathrm{K})\end{array}$} & \multicolumn{3}{|c|}{ Temkin } & \multicolumn{3}{|c|}{ Langmuir } & \multirow{2}{*}{$\begin{array}{c}\operatorname{ssc}_{B} \\
(\mathbf{m M})\end{array}$} & \multirow{2}{*}{$\begin{array}{c}q_{s s c B} \\
\left(\mathbf{m g ~ g}^{-\mathbf{1}}\right)\end{array}$} \\
\hline & & $c_{1}$ & $c_{2}$ & $R^{2}$ & $q_{m o n}$ & K & $R^{2}$ & & \\
\hline \multirow[t]{3}{*}{ Water } & 308 & 11.3 & $1.86 \times 10^{6}$ & 0.96 & 56.0 & $1.64 \times 10^{5}$ & 0.98 & $1.79 \times 10^{-2}$ & 38.3 \\
\hline & 318 & 19.4 & $1.00 \times 10^{6}$ & 0.99 & 100.0 & $9.17 \times 10^{4}$ & 0.98 & $1.40 \times 10^{-2}$ & 50.8 \\
\hline & 328 & 24.0 & $8.64 \times 10^{5}$ & 0.96 & 111.1 & $9.05 \times 10^{4}$ & 0.97 & $1.22 \times 10^{-2}$ & 60.9 \\
\hline $0.1 \mathrm{M} \mathrm{NaCl}$ & 318 & 4.9 & $3.27 \times 10^{8}$ & 0.98 & 34.6 & $8.92 \times 10^{6}$ & 0.99 & $2.50 \times 10^{-3}$ & 37.2 \\
\hline $\mathrm{pH}=10$ & 318 & 5.6 & $8.83 \times 10^{6}$ & 0.98 & 25.9 & $9.37 \times 10^{5}$ & 0.99 & $1.08 \times 10^{-2}$ & 25.5 \\
\hline $\mathrm{pH}=11$ & 318 & 7.0 & $2.64 \times 10^{6}$ & 0.99 & 32.8 & $2.58 \times 10^{5}$ & 0.99 & $2.43 \times 10^{-2}$ & 29.8 \\
\hline $\mathrm{pH}=12$ & 318 & 7.0 & $4.06 \times 10^{6}$ & 0.98 & 34.5 & $3.71 \times 10^{5}$ & 0.97 & $1.07 \times 10^{-2}$ & 25.8 \\
\hline $\mathrm{pH}=13$ & 318 & 13.4 & $7.19 \times 10^{5}$ & 0.99 & 450.5 & $6.55 \times 10^{3}$ & 0.97 & $2.23 \times 10^{-2}$ & 36.3 \\
\hline
\end{tabular}

Dimension of $q_{\text {mon }}$ and $c_{1}$ is in $\mathrm{mg} \mathrm{g}^{-1}$. Dimension of $c_{2}$ and $K$ is in $\mathrm{M}^{-1}$.

Table 3. Parameters obtained from the Temkin and Langmuir equations and $c_{\max }$ and $q_{e \text {, max }}$ values for adsorption of CR on Mg-Al-LDH nanocompound in section IIB (on 003 site) in water, $0.1 \mathrm{M} \mathrm{NaCl}$ and alkaline solutions at 308-328 $\mathrm{K}$.

\begin{tabular}{|c|c|c|c|c|c|c|c|c|c|}
\hline \multirow[t]{2}{*}{ Solvent } & \multirow{2}{*}{$\begin{array}{c}\mathbf{T} \\
(\mathbf{K})\end{array}$} & \multicolumn{3}{|c|}{ Temkin } & \multicolumn{3}{|c|}{ Langmuir } & \multirow{2}{*}{$\begin{array}{c}c_{\max } \\
(\mathbf{m M})\end{array}$} & \multirow{2}{*}{$\begin{array}{c}q_{e, \max } \\
\left(\mathbf{m g ~ g}^{-1}\right)\end{array}$} \\
\hline & & $c_{1}$ & $c_{2}$ & $R^{2}$ & $q_{m o n}$ & K & $R^{2}$ & & \\
\hline \multirow[t]{3}{*}{ Water } & 308 & 47.8 & $1.27 \times 10^{5}$ & 0.98 & 307.0 & $8.36 \times 10^{3}$ & 0.97 & $6.79 \times 10^{-2}$ & 100.0 \\
\hline & 318 & 37.6 & $2.77 \times 10^{5}$ & 0.99 & 153.0 & $3.60 \times 10^{4}$ & 0.99 & $5.66 \times 10^{-2}$ & 105.0 \\
\hline & 328 & 29.7 & $4.24 \times 10^{5}$ & 0.97 & 121.8 & $5.47 \times 10^{4}$ & 0.96 & $5.27 \times 10^{-2}$ & 86.8 \\
\hline $0.1 \mathrm{M} \mathrm{NaCl}$ & 318 & 36.3 & $4.18 \times 10^{5}$ & 0.99 & 158.0 & $4.76 \times 10^{4}$ & 0.99 & $5.84 \times 10^{-2}$ & 116.0 \\
\hline $\mathrm{pH}=10$ & 318 & 34.0 & $2.00 \times 10^{5}$ & 0.99 & 200.0 & $1.49 \times 10^{4}$ & 0.97 & $6.07 \times 10^{-2}$ & 81.6 \\
\hline $\mathrm{pH}=11$ & 318 & 27.3 & $1.23 \times 10^{5}$ & 0.99 & 120.5 & $1.37 \times 10^{4}$ & 0.99 & $8.71 \times 10^{-2}$ & 63.8 \\
\hline $\mathrm{pH}=12$ & 318 & 17.4 & $4.07 \times 10^{5}$ & 0.98 & 75.2 & $4.80 \times 10^{4}$ & 0.97 & $7.83 \times 10^{-2}$ & 60.4 \\
\hline $\mathrm{pH}=13$ & 318 & 19.2 & $2.67 \times 10^{5}$ & 0.97 & 76.9 & $3.76 \times 10^{4}$ & 0.98 & $5.17 \times 10^{-2}$ & 51.1 \\
\hline
\end{tabular}

Dimension of $q_{m o n}$ and $c_{1}$ is in $\mathrm{mg} \mathrm{g}^{-1}$. Dimension of $c_{2}$ and $K$ is in $\mathrm{M}^{-1}$.

was clear that CR molecules orientation in section IIB was parallel to 003 layers, Fig. 8, and due to the negatively charged adsorbent surface, the adsorption interaction was weaker than that in section IIA. Also, it was seen from IR spectra in Figs. 2(a) and 2(b) that due to the interaction of $\mathrm{CR}$ molecule with adsorbent, peaks of $-\mathrm{OH}$ group and $\mathrm{Al}-\mathrm{O}$ stretching mode of Mg-Al-LDH at 3532.9 and 617.1 $\mathrm{cm}^{-1}$ shifted to 3509.8 and $647.9 \mathrm{~cm}^{-1}$ at CR-adsorbed $\mathrm{Mg}$ Al-LDH. Here, the interaction of CR molecule with $-\mathrm{OH}$ group of adsorbent decreased its wavenumber and by shifting electron density of $\mathrm{O}-\mathrm{H}$ bond toward the oxygen atom increased wavenumber of $\mathrm{Al}-\mathrm{O}$ stretching mode. Besides, as seen from Table S1, a large decrease in the relative magnitude of section IIB $\left(\frac{q_{e, \text { max }}-s s C_{B}}{q_{e, \text { max }}}\right)$ resulted in a disorder change of experimental maximum adsorption capacity $\left(q_{e, \text { max }}\right)$ with an increase in temperature, Table 3.

\section{2. Effects of $p H$ and Ionic Strength on the Adsorption of CR on Mg-Al-LDH}

As shown in Tables 1-3, the increase in ionic strength in alkaline and $0.1 \mathrm{M} \mathrm{NaCl}$ solutions had different effects on the adsorption capacity of adsorbent and adsorption binding constants of adsorbate with MP (in region I and section IIA) and 003 (in section IIB) adsorption sites. The ionic atmosphere of $\mathrm{Na}^{+}$ions surrounded interlayer carbonate ions of $\mathrm{Mg}-\mathrm{Al}-\mathrm{LDH}^{55}$ and $\mathrm{CR}$ molecules. The shielding effect of $\mathrm{Na}^{+}$ions decreased the repulsion interaction between CR molecules and Mg-Al-LDH surface and consequently increased the adsorption binding constant values in region I and section IIA compared to those values in water at $318 \mathrm{~K}$. But, the increase in $\mathrm{pH}$ of solutions and neutralization of more - $\mathrm{OH}$ groups of adsorbent increased its negative charge and finally resulted in a decrease in adsorption binding constant of the process at $\mathrm{pH}$ $=13$ compared to that of neutral water at $318 \mathrm{~K}$. Also, adsorption of CR molecules on the Mg-Al-LDH surface increased negative charge of adsorbent surface and finally decreased adsorption binding constant of CR on Mg-Al$\mathrm{LDH}$ from region I to section IIB, Tables 1-3.

On the other hand, the adsorption capacity of $\mathrm{Mg}$ $\mathrm{Al}-\mathrm{LDH}$ for CR molecules in region I, section IIA and section IIB and thus $q_{e, \max }$ decreased with increase in $\mathrm{pH}$ of solution compared to those in water, Tables 1-3.

As reported, ${ }^{55}$ the point of zero charge (pzc) of $\mathrm{Mg}$ $\mathrm{Al}-\mathrm{LDH}$, i.e. the $\mathrm{pH}$ at which the surface charge is neutral, was at $\mathrm{pH}=10$ and the zeta potential of Mg-Al-LDH decreases with increase in pHs. Due to interaction of $\mathrm{OH}^{-}$ions 
with a number of interlayer - $\mathrm{OH}$ groups of $\mathrm{Mg}-\mathrm{Al}-\mathrm{LDH}$, Figs. 2(a), (c) and (d), $-\mathrm{OH}$ and the waveumbers of $\mathrm{Al}-\mathrm{O}$ stretching modes of $\mathrm{Mg}-\mathrm{Al}-\mathrm{LDH}$ at 3532.9 and $617.1 \mathrm{~cm}^{-1}$ shifted to 3502.1 and $655.7 \mathrm{~cm}^{-1}$ in $\mathrm{Mg}-\mathrm{Al}-\mathrm{LDH}$ at $\mathrm{pH}=10$ solution and to 3478.9 and $655.7 \mathrm{~cm}^{-1}$ in $\mathrm{Mg}-\mathrm{Al}-\mathrm{LDH}$ at $\mathrm{pH}$ $=13$ solution. It implied that in alkaline solution interaction of $\mathrm{OH}^{-}$ions with hydrogen atom of $-\mathrm{OH}$ groups of adsorbent surface decreased $-\mathrm{OH}$ wavenumber and by shifting electron density of $\mathrm{O}-\mathrm{H}$ bond to its $\mathrm{O}$ atom caused an increase in wavenumber of $\mathrm{Al}-\mathrm{O}$ vibration stretching mode.

These evidence showed that an increase in $\mathrm{pH}$ value neutralized more - $\mathrm{OH}$ groups of adsorbent. In addition, there was a competition of $\mathrm{OH}^{-}$ions with $\mathrm{CR}$ molecules for interaction with adsorption sites which increased the repulsion interaction between $\mathrm{Mg}$-Al-LDH surface and $\mathrm{CR}$ molecules and resulted in a decrease in the adsorption capacity of adsorbent.

By comparison of results of measurement of the nitrogen-based BET specific surface areas of $\mathrm{Mg}-\mathrm{Al}-\mathrm{LDH}$ and its sample after being in a solution at $\mathrm{pH}=13$, it seems that the hydrogen bonding between $-\mathrm{OH}$ and $-\mathrm{O}^{-}$groups of adsorbent caused its structure shrinkage. As it is clear from Tables 1-3, a decrease in BET surface area and pore volume of $\mathrm{Mg}$-Al-LDH in alkaline solutions could also result in a decrease in the adsorption capacity of adsorbent for CR molecules in alkaline solutions and also the random change in their adsorption binding constants, Tables $1-3$. Because of dissolution of adsorbent and precipitation of congo red in acidic solutions, experiments didn't carry out in acidic pHs.

\section{3. Adsorption Kinetic Equations and Modeling}

The adsorption kinetic experiments were carried out in CR initial concentrations of $0.01,0.06$ and $0.09 \mathrm{mM}$, shaking rates of 30, 70 and $100 \mathrm{rpm}, 0.1 \mathrm{M} \mathrm{NaCl}$ and alka- line (pHs of 10,12 and 13) solutions at 308,318 and $328 \mathrm{~K}$. The adsorption of $0.01 \mathrm{mM}$ CR initial concentration was in region II (section IIA) of the ARIAN thermodynamic model and included just MP adsorption sites. However, the adsorption of 0.06 and $0.09 \mathrm{mM} \mathrm{CR}$ initial concentration were in the region II (section IIB) of this model and included both MP and 003 sites. The results were analyzed by the KASRA model and ISO and intraparticle diffusion
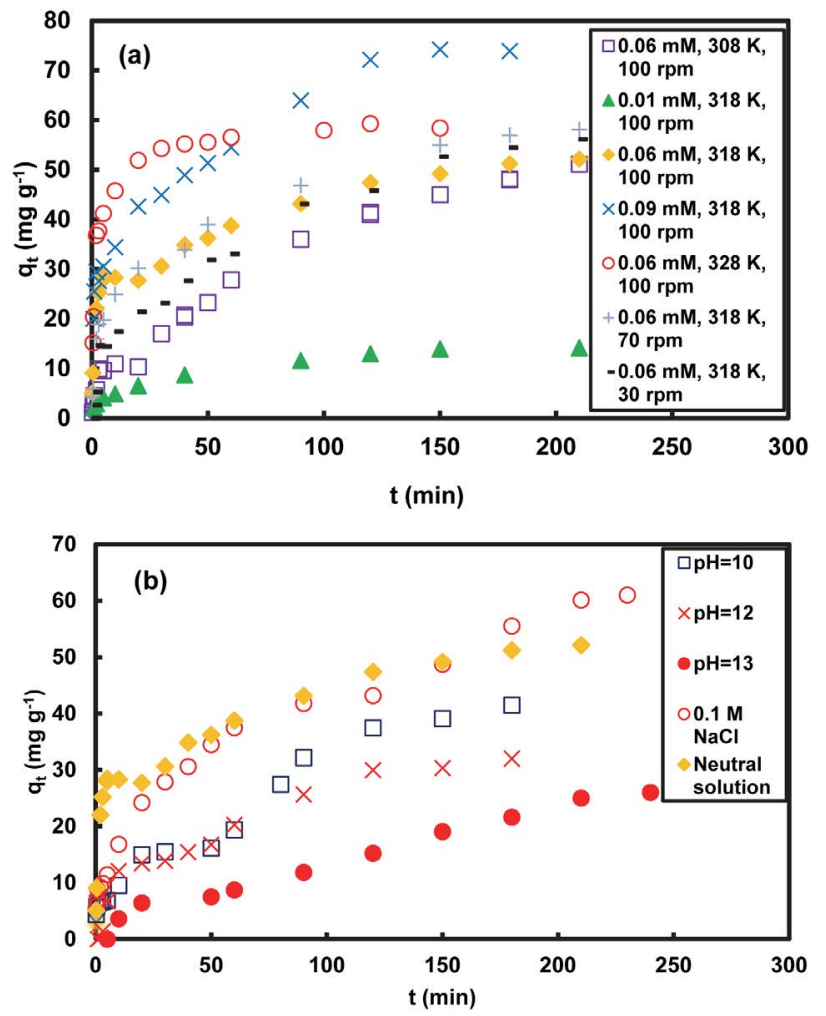

Figure 9. $q_{t} v s . c_{t}$ for adsorption of $\mathrm{CR}$ on Mg-Al-LDH nanocompound (a) from CR solutions at different temperatures, shaking rates and initial concentrations and (b) from $0.06 \mathrm{mM} \mathrm{CR}$ in water, $0.1 \mathrm{M} \mathrm{NaCl}$ and alkaline solutions at $318 \mathrm{~K}$ and $100 \mathrm{rpm}$.

Table 4. TDs and TRAKs for adsorption of $\mathrm{CR}$ on $\mathrm{Mg}$-Al-LDH nanocompound in water, $0.1 \mathrm{M} \mathrm{NaCl}$ and alkaline solutions at $308-328 \mathrm{~K}$.

\begin{tabular}{|c|c|c|c|c|c|c|c|c|}
\hline Solvent & $\begin{array}{c}T \\
(\mathbf{K})\end{array}$ & $\begin{array}{l}{[C R]_{0}} \\
(\mathrm{mM})\end{array}$ & rpm & $\begin{array}{c}T D \\
(\mathrm{~min})\end{array}$ & $\begin{array}{c}T R A K_{C_{1}-C_{2}} \\
\quad(\min )\end{array}$ & $\begin{array}{c}T R A K_{C_{2}-C_{3}} \\
(\min )\end{array}$ & $\begin{array}{c}t_{e} \\
(\mathrm{~min})\end{array}$ & $\begin{array}{c}q_{e} \\
\left(\mathbf{m g ~ g}^{-1}\right)\end{array}$ \\
\hline \multirow[t]{7}{*}{ Water } & 318 & 0.01 & 100 & - & - & - & 150 & 13.9 \\
\hline & 308 & 0.06 & 100 & - & $3-20$ & - & 180 & 48.0 \\
\hline & 318 & 0.06 & 100 & - & $3-20$ & - & 150 & 49.2 \\
\hline & 318 & 0.09 & 100 & - & $2-5$ & - & 150 & 74.2 \\
\hline & 318 & 0.06 & 70 & - & $3-5$ & - & 180 & 57.0 \\
\hline & 318 & 0.06 & 30 & $0-0.5$ & $2-5$ & - & 180 & 54.4 \\
\hline & 328 & 0.06 & 100 & - & $2-3$ & - & 30 & 54.3 \\
\hline $0.1 \mathrm{M} \mathrm{NaCl}$ & 318 & 0.06 & 100 & - & $1-3$ & $90-120$ & 210 & 60.1 \\
\hline $\mathrm{pH}=10$ & 318 & 0.06 & 100 & - & $0.75-5$ & $30-50$ & 180 & 41.5 \\
\hline $\mathrm{pH}=12$ & 318 & 0.06 & 100 & $0-2$ & $10-40$ & - & 120 & 30.0 \\
\hline $\mathrm{pH}=13$ & 318 & 0.06 & 100 & $0-5$ & $20-50$ & - & 240 & 26.0 \\
\hline
\end{tabular}

$T R A K_{C_{1}-C_{2}}$ and TRAK $K_{C_{2}-C_{3}}$ are the observed TRAKs between the first and second kinetic curves and between the second and third kinetic curves, respectively. $t_{e}$ and $q_{e}$ are the time and adsorption capacity of starting plateau and reaching equilibrium. 
equations, Figs. 9(a) and (b), Tables 4 and 5 and S2-S4. As shown in Table 4, there was a TD at the beginning of adsorption in $0.06 \mathrm{mM}$ of $\mathrm{CR}$ at $30 \mathrm{rpm}$ and $0.06 \mathrm{mM}$ of CR at $100 \mathrm{rpm}$ and pHs of 12 and 13. The observed TD at 30 rpm was due to the low rate of CR diffusion to the surface of adsorbent and the TDs at pHs of 12 and 13 were due to negatively-charged surface of adsorbent which was generated by the neutralization of a number of $-\mathrm{OH}$ groups of adsorbent.

In this study, $T R A K_{C_{1}-C_{2}}$ showed the time delay range between adsorption on $\mathrm{MP}$ and 003 sites and $T R A K_{\mathrm{C}_{2}-C_{3}}$ identified the time delay range between two steps of adsorption on 003 sites. These TRAKs happened because of repulsion interaction between negatively charged CR-adsorbed Mg-Al-LDH with CR molecules in the solution.

The adsorption of $0.01 \mathrm{mM}$ of CR initial concentration was in section IIA (based on the ARIAN thermodynamic model) and CR molecules were adsorbed on MP site. The analysis of kinetic data of $0.01 \mathrm{mM}$ of CR initial concentration by the KASRA model showed that it was placed in regions 1 and 2 of its kinetic curves. But, the adsorptions using the initial concentrations of 0.06 and $0.09 \mathrm{mM} \mathrm{CR}$ were in section IIB (based on the ARIAN thermodynamic model) and $\mathrm{CR}$ molecules were adsorbed on MP (in region I and section IIA) and 003 sites (in section IIB). The kinetic study of both concentrations ( 0.06 and $0.09 \mathrm{mM}$ ) by the KASRA model showed that they were in region1 (adsorbed on MP sites) and region 2 (adsorbed on 003 sites), Tables 5 and S2. An increase in ionic strength in $0.1 \mathrm{M}$ of $\mathrm{NaCl}$ and $\mathrm{pH}=10$ resulted in observing the third kinetic curves in these cases.
Also the analysis of adsorption results of CR on MP sites of Mg-Al-LDH by the KASRA model and intraparticle diffusion equation showed that adsorption acceleration, velocity and $k_{d i f}$ increased with the increase of experimental variables, such as initial concentration of CR, shaking rate, ionic strength and temperature. An opposite trend was observed to those kinetic parameters, when $\mathrm{pH}$ of solution was increased. This confirmed that adsorption kinetics on MP site was reaction-controlled, Tables 5 and S3. But, the adsorption acceleration and the velocity of adsorption of CR on 003 sites were approximately constant with increase in above-mentioned factors. The results verified that the adsorption kinetics was diffusion-controlled, Tables S2 and 5. As the CR concentration in the solution dropped during the course of adsorption, the adsorption acceleration, velocity and $k_{d i f}$ values decreased from region 1 to region 2, Tables S2, S3 and 5.

As seen in Table 5, in $0.1 \mathrm{M} \mathrm{NaCl}$ and $\mathrm{pH}$ of 10 solutions, adsorption was continued after the second TRAK and formed the third kinetic curves. This occurred because $\mathrm{Na}^{+}$ionic atmosphere surrounding adsorbent surface and CR molecules decreased the repulsion interaction between them. As shown in Table $5, k_{d i f}$ values of these two processes were similar to $k_{\text {dif }}$ values of other adsorption processes in the second kinetic curves. Thus, in the third kinetic curve, the adsorption kinetics of CR molecules towards 003 sites was diffusion-controlled.

On the other hand, a detailed study of kinetic data by the ISO equation showed that $k_{I 1}$ values for the adsorption of CR on MP sites (similar to trend of changes in the adsorption acceleration, velocity and $k_{\text {dif }}$ parameters) in-

Table 5. Adsorption acceleration values, intraparticle diffusion constants and ISO rate constants for kinetics of CR adsorption on Mg-Al-LDH nanocompound at different temperatures and in various shaking rates and initial CR concentrations.

\begin{tabular}{|c|c|c|c|c|c|c|c|c|c|c|c|c|c|}
\hline \multirow[t]{2}{*}{ Solvent } & \multirow[t]{2}{*}{$\begin{array}{c}T \\
(\mathbf{K})\end{array}$} & \multirow[t]{2}{*}{$\begin{array}{l}{[C R]_{0}} \\
(\mathrm{mM})\end{array}$} & \multirow[t]{2}{*}{ rpm } & \multicolumn{3}{|c|}{$\begin{array}{l}\text { KASRA region } 1 \\
\text { (1 st curve) }\end{array}$} & \multicolumn{4}{|c|}{ KASRA region 2 ( 1 st curve) } & \multirow[b]{2}{*}{$a_{3}$} & \multirow[b]{2}{*}{$\boldsymbol{k}_{\text {dif }}$} & \multirow[b]{2}{*}{$k_{D b}$} \\
\hline & & & & $a_{1}$ & $\boldsymbol{k}_{\text {dif }}$ & $k_{I 1}$ & $a_{2}$ & $\boldsymbol{k}_{\text {dif }}$ & $k_{I 2 a}$ & $k_{I 2 b}$ & & & \\
\hline \multicolumn{4}{|c|}{ Corresponding to thermodynamic } & \multicolumn{3}{|c|}{ ARIAN region I (MP Site) } & \multicolumn{4}{|c|}{ ARIAN section IIA (MP Site) } & & & \\
\hline Water & 318 & 0.01 & 100 & -0.45 & 1.85 & $6.34 \times 10^{4}$ & -0.001 & 1.0 & $3.05 \times 10^{4}$ & $6.81 \times 10^{4}$ & - & - & - \\
\hline \multicolumn{3}{|c|}{$\begin{array}{l}\text { Corresponding } \\
\text { to thermodynamic }\end{array}$} & \multicolumn{4}{|c|}{$\begin{array}{l}\text { KASRA region } 1 \text { (1st curve) } \\
\text { ARIAN region I and section II A } \\
\text { (MP Site) }\end{array}$} & \multicolumn{3}{|c|}{$\begin{array}{l}\text { KASRA region } 2 \text { ( } 2 \text { nd curve) } \\
\text { ARIAN section IIB (003 Site) }\end{array}$} & \multicolumn{4}{|c|}{$\begin{array}{l}\text { KASRA region } 2 \text { (3rd curve) } \\
\text { ARIAN section IIB } \\
\text { (003 Site) }\end{array}$} \\
\hline \multirow[t]{6}{*}{ Water } & 308 & 0.06 & 100 & -3.54 & 4.36 & $1.75 \times 10^{5}$ & -0.002 & 4.2 & $1.57 \times 10^{4}$ & $2.35 \times 10^{4}$ & - & - & - \\
\hline & 318 & 0.06 & 100 & -5.70 & 15.5 & $5.01 \times 10^{5}$ & -0.002 & 2.8 & $2.00 \times 10^{4}$ & $4.76 \times 10^{4}$ & - & - & - \\
\hline & 318 & 0.09 & 100 & -20.40 & 21.7 & $1.22 \times 10^{6}$ & -0.003 & 4.5 & $1.64 \times 10^{4}$ & $5.97 \times 10^{4}$ & - & - & - \\
\hline & 318 & 0.06 & 70 & -3.52 & 11.4 & $3.18 \times 10^{5}$ & -0.002 & 3.3 & $1.64 \times 10^{4}$ & $3.72 \times 10^{4}$ & - & - & - \\
\hline & $318^{\star}$ & 0.06 & 30 & -1.52 & 20.9 & $2.15 \times 10^{5}$ & -0.002 & 3.8 & $1.13 \times 10^{4}$ & $3.69 \times 10^{4}$ & - & - & - \\
\hline & 328 & 0.06 & 100 & -14.66 & 25.9 & $7.37 \times 10^{5}$ & -0.05 & 4.5 & $1.13 \times 10^{5}$ & $6.33 \times 10^{5}$ & - & - & - \\
\hline $0.1 \mathrm{M} \mathrm{NaCl}$ & 318 & 0.06 & 100 & -11.69 & 8.6 & $3.65 \times 10^{5}$ & -0.008 & 4.3 & $2.72 \times 10^{4}$ & - & $5.4 \times 10^{-4}$ & 4.9 & $2.93 \times 10^{4}$ \\
\hline $\mathrm{pH}=10$ & 318 & 0.06 & 100 & -29.94 & 7.5 & $5.26 \times 10^{5}$ & -0.034 & 2.8 & $5.33 \times 10^{4}$ & - & -0.004 & 4.7 & $2.16 \times 10^{4}$ \\
\hline $\mathrm{pH}=12^{*}$ & 318 & 0.06 & 100 & -0.25 & 8.0 & $5.67 \times 10^{4}$ & -0.002 & 3.2 & $4.90 \times 10^{3}$ & $1.59 \times 10^{4}$ & - & - & - \\
\hline $\mathrm{pH}=13^{*}$ & 318 & 0.06 & 100 & -0.06 & 2.8 & $1.77 \times 10^{4}$ & $-3.0 \times 10^{-4}$ & 2.3 & $5.22 \times 10^{3}$ & $2.51 \times 10^{4}$ & - & - & - \\
\hline
\end{tabular}

Units of $a_{1}, a_{2}$ and $a_{3}$ are in $\mathrm{mg} \mathrm{g}^{-1} \mathrm{~min}^{-2}$. Unit of $k_{d i f}$ is in $\mathrm{mg} \mathrm{g}^{-1} \mathrm{~min}^{-0.5}$. Units of $k_{I 1}, k_{I 2 a}$ and $k_{I 2 b}$ are in $\mathrm{mg} \mathrm{g}^{-1} \mathrm{M}^{-1} \mathrm{~min}^{-1}$. Except for $0.01 \mathrm{mM}$ of $\mathrm{CR}$, there is a TRAK between each two successive kinetic curves (Table 4). ${ }^{*}$ There is a TD (time delay) before the first curve (Table 4). 
creased with increase in initial concentration of CR, shaking rate, ionic strength and temperature and decreased with the increase in solution's $\mathrm{pH}$ values, Tables S4 and 5. An increase in $\mathrm{pH}$ increased the negative charge of adsorbent surface and thus increased the repulsion interaction between CR molecules and adsorbent. This consequently decreased kinetic parameters values.

Results showed that kinetics of adsorption of CR on MP site was reaction-controlled ${ }^{51}$ and its $E_{\text {act }}$ by using $k_{I 1}$ values at $308-328 \mathrm{~K}$ was $60.7 \mathrm{~kJ} \mathrm{~mol}^{-1}$.

For the adsorption of CR on 003 sites, $k_{12 a}$ values (in part 2a), except at $328 \mathrm{~K}$ and pHs of 12 and 13, were similar to each other and $k_{I 2 a}$ values in the range of $308-328 \mathrm{~K}$ did not obey the Arrhenius equation. This showed that in part 2a the diffusion of CR molecules towards adsorbent surface was rate-controlling step, Table 5, which was similar with the adsorption of CR on GO/PAMAM. ${ }^{49}$ A decrease in $k_{12 a}$ values with the increase in $\mathrm{pH}$ was due to an increase in the repulsion interaction between the adsorbent surface and adsorbed CR molecules. Also, $k_{I 2 b}$ values did not obey from Arrhenius equation which showed that in part 2b (like part 2a) kinetics of CR adsorption was diffusion-controlled, ${ }^{49}$ Table 5.

\section{Conclusions}

Adsorption of congo red (CR) on Mg-Al-LDH was carried out under different $\mathrm{CR}$ initial concentrations, alkaline $\mathrm{pHs}$, temperatures, ionic strengths and shaking rates. Based on adsorbent structure and IR spectra it was clear that adsorption site of adsorbent were $-\mathrm{OH}$ groups attached to $\mathrm{Al}$ atoms of adsorbent layers. Analysis of adsorption isotherms by the ARIAN model showed that there were two types of adsorption sites on the adsorbent. These adsorption sites were $-\mathrm{OH}$ groups attached to $\mathrm{Al}$ atoms located in the surface of mesopores (named as MP sites) and micropores located in interlayer galleries between (003) layers (named as 003 sites) of adsorbent. Based on the ARIAN model, MP sites were in region I and section IIA and 003 sites were in section IIB. Adsorption in region I and sections IIA and IIB were endothermic, exothermic and endothermic, respectively. Kinetic data were analyzed by the KASRA model and ISO and intraparticle diffusion equations. It was verified that CR adsorption at first occurred on MP sites and its adsorption kinetics was reaction-controlled. Then, CR was adsorbed on 003 sites and the kinetics of adsorption on them was diffusion-controlled.

\section{References}

1. M. Ghaedi, H. Tavallali, M. Sharifi, S. N. Kokhdan and A. Asghari, Spectrochimica Acta Part A, 2012, 86, 107-114.

DOI:10.1016/j.saa.2011.10.012
2. S. Maeda, S. Hongyou, K. Kunitou and K. Mishima, TRJ, 2002, 72, 240-244. DOI:10.1177/004051750207200310

3. I. A. Bhatti, S. Adeel, S. Siddique and M. Abbas, J. Saudi. Chem. Soc., 2014, 18, 606-609.

DOI:10.1016/j.jscs.2012.11.006

4. A. Hebeish, A. Waly and F. A. Abdel Mohdy, Macromol. Mater.Eng., 1981, 95, 55-66. DOI:10.1002/apmc.1981.050950105

5. K. A. Amina, H. Abdel Hameid and A. H. Abd Elsttar, Food Chem. Toxicol., 2010, 48, 2994-2999.

DOI:10.1016/j.fct.2010.07.039

6. A. Guerra-Tapia and E. Gonzalez-Guerra, Actas Dermosifiliogr., 2014, 105, 833-839. DOI:10.1016/j.ad.2014.02.004

7. J. O. B. Boahin, J. Adu-Agyem and Y. S. Peligah, JST, 2011, 31, 68-73. DOI:10.4314/just.v31i2.69395

8. H. Ali, Water, Air and Soil Pollution, 2010, 213, 251-273. DOI:10.1007/s11270-010-0382-4

9. A. Y. Zahrim and N. Hilal, Water Resources and Industry, 2013, 3, 23-34. DOI:10.1016/j.wri.2013.06.001

10. X. Ma, P. Chen, M. Zhou, Z. Zhong, F. Zhang and W. Xing, Ind. Eng. Chem. Res., 2017, 56, 7070-7079.

DOI:10.1021/acs.iecr.7b01440

11. İ. Arslana, I. A. Balcioğlua and D. W. Bahnemann, Dyes and Pigments, 2000, 47, 207-218.

DOI:10.1016/S0143-7208(00)00082-6

12 S. Karcher, A. Kornmüller and M. Jekel, Water Research, 2002, 36, 4717-4724. DOI:10.1016/S0043-1354(02)00195-1

13. M. T. Yagub, T. K. Sen, S. Afroze and H. M. Ang, Adv. Colloid Interface Sci., 2014, 209, 172-184.

DOI:10.1016/j.cis.2014.04.002

14. K. Hunger, P. Mischke, W. Rieper, R. Raue, K. Kunde and Aloys Engel: "Azo Dyes" in Ullmann's Encyclopedia of Industrial Chemistry, Wiley-VCH, Weinheim, 2005.

15. G. Klatskin, Am. J. Pathol., 1969, 56, 1-13. DOI:10.1484/J.MSS.3.601

16. M. A. Mohammad Razi, M. N. A. Mohd Hishammudin and R. Hamdan, MATEC Web of Conferences 2017, 103, 06015. DOI:10.1051/matecconf/201710306015

17. A. Afkhami and R. Moosavi, J. Hazard. Mater., 2010, 174, 398-403. DOI:10.1016/j.jhazmat.2009.09.066

18. A. C. Jalandoni-Buan, A. L. A. Decena-Soliven, E. P. Cao, V. L. Barraquio and W. L. Barraquio, Philipp. J. Sci., 2010, 139, 71-78.

19. E. Lorenc-Grabowska and G. Gryglewicz, Dyes and Pigments, 2007, 74, 34-40. DOI:10.1016/j.dyepig.2006.01.027

20. Y. Zhou, L. Ge, N. Fan and M. Xia, Adsorpt. Sci. Technol., 2018, 36, 1310-1330. DOI:10.1177/0263617418768945

21. D. Maiti, S. Mukhopadhyay and P. S. Devi, ACS Sustainable Chem. Eng., 2017, 5, 11255-11267.

DOI:10.1021/acssuschemeng.7b01684

22. Z. X. Tang, Y. Chen, J. Xue and S. Yue, Adv. Mater. Res., 2012, 503-504, 262-265.

DOI:10.4028/www.scientific.net/AMR.503-504.262

23. V. Vimonse, S. Lei, B. Jin, C. W. K. Chow and C. Saint, Appl. Clay Sci., 2009, 4, 465-472. DOI:10.1016/j.clay.2008.11.008

24. Y. H. Zhan and J. W. Lin, Huan Jing ke Xue, 2013, 34, 31433150 . 
25. C. Namasivayam and R. T. Yamuna, JCTB, 1992, 53, 153-157. DOI: $10.1002 /$ jctb. 280530208

26. G. Mishra, B. Dash and S. Pandey, Appl. Clay Sci., 2018, 153, 172-186. DOI:10.1016/j.clay.2017.12.021

27. D. G. Evans and R. C. T. Slade, Struct. Bond., 2006, 119, 1-87.

28. B. Zümreoglu-Karan, Chemical Papers, 2012, 66, 1-10. DOI:10.2478/s11696-011-0100-8

29. Q. Wang and D. O'Hare, Chem. Rev., 2012, 112, 4124-4155. DOI: $10.1021 / \mathrm{cr} 200434 \mathrm{v}$

30. H. Acharya, S. K. Srivastava and A. K. Bhowmick, Compos. Sci. Technol., 2007, 67, 2807-2816.

DOI:10.1016/j.compscitech.2007.01.030

31. M. Herrero, P. Benito, F. M. Labajos, V. Rives, Y. D. Zhu, G. C. Allen and J. M. Adams, J. Solid State Chem., 2010, 183, 16451651. DOI:10.1016/j.jssc.2010.05.014

32. A. Halajnia, S. Oustan, N. Najafi, A. R. Khataee and A. Lakzian, Appl. Clay Sci., 2013, 80-81, 305-312.

DOI:10.1016/j.clay.2013.05.002

33. Y. You, G. F. Vance and H. Zhao, Appl. Clay Sci., 2001, 20, 13-25. DOI:10.1016/S0169-1317(00)00043-0

34. N. Baliarsingh, L. Mohapatra and K. Parida, J. Mater. Chem. $A$, 2013, 1, 4236-4243. DOI:10.1039/c2ta00933a

35. T. Li, H. N. Miras and Y. F. Song, Catalysts, 2017, 7, 260. DOI:10.3390/catal7090260

36. F. Zhang, Z. G. Liu, R. C. Zeng, S. Q. Li, H. Z. Cui, L. Song and E. H. Hanc, Surf. Coat. Technol., 2014, 258, 1152-1158. DOI:10.1016/j.surfcoat.2014.07.017

37. J. Liu, Z. Zhan, M. Yu, Q. Wang, J. Zhang and M. Wang, Surf. Interface Anal., 2012, 44, 863-869. DOI:10.1002/sia.4923

38. E. Ge'raud, V. Pre'vot and F. Leroux, J. Phys. Chem. Solids, 2006, 67, 903-908. DOI:10.1016/j.jpcs.2006.01.002

39. M. Ogawa and H. Kaiho, Langmuir, 2002, 18, 4240-4242. DOI:10.1021/la0117045

40. W. Z. Yin, Q. Tan, L. Liu and X. L. Li, Adv. Mat. Res., 2012, 454, 101-104. DOI:10.4028/scientific5/AMR.454.101
41. T. Kameda, M. Saito and Y. Umetsu, Mater. Trans., 2006, 47, 923-930. DOI:10.2320/matertrans.47.923

42. N. Ayawei, S. S. Angaye, D. Wankasi and E. D. Dikio, Open Journal of Physical Chemistry, 2015, 5, 56-70.

DOI:10.4236/ojpc.2015.53007

43. E. Otgonjargal, G. Burmaa, B. Enkhmaa, M. Enkhtuul, L. Nyam-Ochir, S. Ryun and D. Khasbaatar, Mong. J. Chem., 2014, 15, 36-39. DOI:10.5564/mjc.v15i0.319

44. Z. P. Xu, G. Stevenson, C. Q. Lu and G. Q. Lu, J. Phys. Chem. B, 2006, 110, 16923-16929. DOI:10.1021/jp062281o

45. K. S. W. Sing, D. H. Everett, R. A. W. Haul, L. Moscou, R. A. Pierotti, J. Rouquerol and T. Siemieniewska, Pure Appl. Chem., 1985, 57, 603-619.

46. B. Samiey and S. Golestan, Cent. Eur. J. Chem., 2010, 8, 361369. DOI:10.2478/s11532-009-0135-7

47. B. Samiey and S. Abdollahi Jonaghani, J. Pollut. Eff. Con., 2015, 3, 2.

48. I. Langmuir, J. Am. Chem. Soc., 1918, 40, 1361-1403. DOI:10.1021/ja02242a004

49. M. Boudart and G. Djega-Mariadassou, Kinetics of Heterogeneous Catalytic Reactions, University Press, Princeton, NJ, 1984. DOI: $10.1515 / 9781400853335$

50. M. Rafi, B. Samiey and C.-H. Cheng, Materials, 2018, 11, 496. DOI:10.3390/ma11040496

51. M. Ozacar, I.A. Şengil, Colloids Surf. A, 2004, 242, 105-113.

52. B. Samiey and S. Farhadi, Acta Chim. Slov., 2013, 60, 763-773.

53. S. Nam, R. Slopek, B. D. Condon and P. Sawhney, TRJ, 2015, 85, 1221-1233. DOI:10.1177/0040517514561918

54. B. Samiey and A. Dadkhah Tehrani, JCCS, 2015, 62, 149-162. DOI:10.1002/jccs.201400093

55. Q. Wang, Y. Gao, J. Luo, Z. Zhong, A. Borgna, Z. Guo and D. O'Hare, RSC Advances, 2013, 3, 3414-3420.

DOI:10.1039/c2ra22607c

\section{Povzetek}

V delu je opisana uporaba plastovitih Mg-Al- dvojnih hidroksidov (Mg-Al-LDH) z interkaliranim karbonatom kot adsorbentom za odstranjevanje kongo rdečega (CR). Šaržni adsorpcijski eksperimenti so bili izvedeni pri različnih temperaturah, ionski moči, začetnih koncentracijah CR, alkalnosti in stresanju. Maksimalne adsorpcijske kapacitete Mg-AlLDH za CR so znašale $100 \mathrm{mg} \mathrm{g}^{-1}$ pri temperaturi $308 \mathrm{~K}, 105$ pri $310 \mathrm{~K}$ in 86.6 pri $328 \mathrm{~K}$. Adsorpcijska mesta na katere se je $\mathrm{CR}$ vezal so bile $-\mathrm{OH}$ skupine vezane na $\mathrm{Al}$ atome. Adsorpcijske izoterme so bile analizirane $\mathrm{z}$ modelom ARIAN. Izkazalo se je, da obstaja dva tipa adsorpcijskih mest na površini Mg-Al-LDH. Rezultati instrumentalne analize so pokazali, da gre v obeh primerih za -OH skupine, enkrat prisotne v mezoporah, poimenovane MP, in enkrat v mikroporah, poimenovane 003. Rezultati kinetičnih meritev so bili analizirani z modelom KASRA, ISO ter enačbami, ki opisujejo difuzijo v porah. Analiza je pokazala, da se CR molekule najprej vežejo na MP mesta, kjer predstavlja interakcija s površino limitni korak. Po drugi strani pa se je izkazalo, da je adsorpcija na 003 mesta difuzijsko omejena. 